\title{
SOX18 wt Allele
}

National Cancer Institute

\section{Source}

National Cancer Institute. SOX18 wt Allele. NCI Thesaurus. Code C79747.

Human SOX18 wild-type allele is located in the vicinity of $20 q 13.33$ and is approximately 2 $\mathrm{kb}$ in length. This allele, which encodes transcription factor SOX-18 protein, is involved in the regulation transcription. Mutations in the gene are associated with hypotrichosislymphedema-telangiectasia syndrome. 